\title{
PARTITIVE SUBJECTS IN ESTONIAN DIALECTS
}

\author{
Liina Lindström \\ University of Tartu
}

\begin{abstract}
Nominative-partitive alternation in subject marking in Estonian occurs mainly in existentials and related constructions. The paper measures the overall frequency of use of partitive subjects (PS) in Estonian dialects to explore whether differences are found, which can be explained by language contacts. Second, it provides an overview of constructions where PSs occur in Estonian dialects. The data is obtained from the Corpus of Estonian Dialects (12 subdialects, 1517 instances of PS usage). The results show that in usage frequency of PSs, Estonian dialects are relatively uniform and there are no striking differences between the dialects. The use of PSs was less frequent in Northern-Seto (a South-Estonian subdialect, in the Russian contact area), where the use of PSs is more tightly associated with negative clauses than it is in other dialects. Negation is also generally the most powerful factor conditioning the use of PSs (explains $52 \%$ of the usages of PSs).
\end{abstract}

Keywords: dialect syntax, partitive subject, differential subject marking, Estonian

DOI: https://doi.org/10.12697/jeful.2017.8.2.07

\section{Introduction}

Estonian has the option of using partitive subjects which alternate with nominative subjects, representing the Differential Subject Marking phenomenon (DSM, see e.g. de Hoop and de Swart 2008). The alternation occurs in marked clause types with XVS word order (Erelt and Metslang 2006), mainly in existential clauses (1) and possessive clauses (2).

'There were books on the table.' 

(2) Mu-l on une-d sõbra-d / uusi sõpru.
I-ADE be.PR.3 new-PL.NOM friend-PL.NOM / new.PL.PRT friend.PL.PRT
I have new friends.'

In existential clauses, the clause-initial adverbial typically expresses location or time; in possessive clauses, the clause-initial adessivemarked adverbial refers to the possessor. If the subject is case-marked with the partitive, the verb is always in the 3rd person singular form, while the nominative triggers subject-verb agreement in number and person. In negative existential/possessive clauses, partitive case marking of the subject is obligatory (3) and the nominative cannot be used.

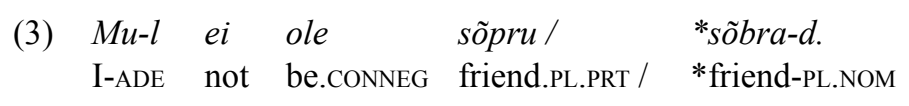

'I do not have any friends.'

In earlier research, a number of semantic conditions for the use of either the nominative or the partitive have been described (inter alia, Rannut 1964, Erelt et al. 1993, Nemvalts 2000). More recently, the Estonian nominative-partitive case alternation system has also been analysed from the point of view of differential subject marking and differential object marking (Metslang 2012, 2014) and in comparison with other Finnic languages (Lees 2008, 2015). However, most of the studies carried out on this topic focus on the core domain of the alternation, i.e. existential and possessive clauses, but we still lack knowledge of where else the alternation occurs. Another related problem is that so far, only a few studies have been based on actual corpus data: Metslang uses a small dataset from written Estonian (Metslang 2012, 2014), Lees has used only Biblical texts (Lees 2008, 2015). Thus we lack knowledge about the actual usage of partitive subjects in spoken Estonian, dialects or other registers. In this paper, I aim to fill this gap by examining at the distribution of partitive subjects in Estonian dialects, based on data from the Corpus of Estonian dialects ${ }^{1}$. On the one hand, I compare frequency of use of partitive subjects (PS) in different dialects; on the other hand, I provide an overview of different constructions where the PSs can be used in the dialects.

Partitive-nominative alternation in subject marking occurs in all Baltic-Finnic languages (Laanest 1975) and it has been regarded as an

$1<$ http://www.keel.ut.ee/et/keelekogud/murdekorpus $>$ 
old feature of these languages (Larjavaara 1991). Its origin has been a matter of discussion for many researchers; generally, it has been connected to the similar phenomenon in Baltic and Slavic languages, where it is called the independent genitive or partitive-genitive (Larjavaara 1991, Larsson 2001, Koptjevskaja-Tamm and Wälchli 2001, Bjarnadóttir and De Smit 2013, Seržant 2015). The alternation is attested in all Baltic-Finnic languages, Latvian, Lithuanian, Latgalian, Russian (esp. North-Russian), i.e. in Eastern Circum-Baltic languages, and is an areal feature (Seržant 2015). Its use is much more restricted in other Slavic languages that do not belong to the Circum-Baltic core area, such as Polish, Czech, and Sorbian (Koptjevskaja-Tamm and Wälchli 2001: 660). However, the use of DSM also differs within the Circum-Baltic area, e.g. in Latvian, the use of the partitive-genitive has been retained only with the negated verb büt 'be' (Koptjevskaja-Tamm and Wälchli 2001: 660). The use of the partitive (or the corresponding genitive) is related mainly to quantification and negation in Eastern Circum-Baltic languages (Koptjevskaja-Tamm and Wälchli 2001: 658); in Baltic-Finnic languages, however, the alternation is the most systematic and widespread, especially in the marking of quantitative indefiniteness (Larjavaara 1991).

The use of PSs is thus a relatively old feature in Baltic-Finnic languages. There are some differences between Finnic languages in usage patterns and overall frequency of nominative or partitive marking of intransitive subjects. For example, based on Biblical texts from Estonian, Finnish, Veps, Livonian and Karelian, Lees has found differences in the use of partitive and nominative subjects in these languages (Lees 2008 , 2015). Although her data is rather limited, it appears that in Livonian the nominative is more frequent in existentials than in other Finnic languages and can be used even in negative existential and possessive clauses. In Estonian, Veps and Livonian, nominative plural subjects in existential clauses trigger verb agreement (Lees 2008). In Karelian spoken in the Valdai region, the use of partitive subjects is reported to be more limited and it is used mainly in negative existentials; PSs occur only marginally in affirmative existentials and related clause types. The restricted use of PSs has been interpreted as an influence of Russian (Leppik 1962).

My main hypothesis, based on the variation within the BalticFinnic group illustrated above, concerns the use of partitive subjects in Estonian dialects: I assume that there is some variation in the overall frequency of PSs, as well as in usage patterns. I expect that the usage 
frequency is more or less in correlation with local language contacts: PSs are expected to occur more often in subdialects that have had longlasting contacts with languages with (more or less) systematic DSM (North Russian, other Finnic languages), and the use of PSs is expected to have decreased in subdialects that have had more contacts with languages lacking DSM (Swedish, German). Latvian can be counted here as a language with relatively rare use of partitive genitive.

In the next section, some general information is provided about the partitive-nominative alternation in Estonian. Estonian dialects and the data used in this study are introduced in section 3. In section 4, the focus is on possible differences between the dialects, based on quantitative analysis. Different constructions taking PSs are presented in section 5.

\section{Semantic conditions determining the use of PSs}

The interplay between the nominative and the partitive has interested many researchers, and the main focus of the research has been on the semantic conditions which determine the use of the nominative and partitive in marking the subject (cf. Rannut 1964, Mihkla et al. 1974, Erelt et al. 1993, Nemvalts 2000, Metslang 2012). Here I summarize the basic conditions that motivate partitive marking.

Construction (clause type). The alternation takes place mainly in existential and possessive clauses (Rannut 1964, Erelt et al. 1993, Nemvalts 2000, Metslang 2012). More seldom, PS can also be used in source-marking clauses and experiential clauses (Huumo and Lindström 2014, Lees 2015: 373-375), but as of yet there is no exhaustive account of these usages. Some additional constructions are discussed in the subsequent sections of this paper (sections 5.4 and 5.5).

Negation. The partitive subject is obligatory in negative existential (5), (7). The requirement of using the partitive in has often been seen as a criterion for defining existentials. (Nemvalts 2000)

Divisibility of the subject referent. If the subject referent is not divisible (a single count noun, e.g. tool 'chair'), only the nominative can be used (4), except when negated (5). The partitive may occur if the referent is divisible (mass noun, abstract noun, or plural count noun), and the quantity is indefinite (6) (Rannut 1964). With divisible referents that are quantitatively definite, the nominative is used in affirmatives, providing the meaning 'a set of' (8). Example (8), however, is ambiguous since it can also be interpreted as neutral with respect to 
quantitative definiteness: it can be used when the amount of chairs is unimportant.

(4) Köögi-s on tool.

kitchen-INE be.3 chair.SG.NOM

'There is a chair in the kitchen'

(5) Köögi-s ei ole tooli.

kitchen-INE not be.CONNEG chair.SG.PRT

'There is no chair in the kitchen'

(6) Köögi-s on toole.

kitchen-INE be.3 chair.PL.PRT

'There are (some) chairs in the kitchen'

(7) Köögi-s ei ole toole.

kitchen-INE not be.CONNEG chair.PL.PRT

'There are no chairs in the kitchen'

(8) Köögi-s on tooli-d.

kitchen-INE be.3 chair-PL.NOM

'There are chairs in the kitchen'

However, this schema only works on a very general level. There are more semantic and syntactic factors that condition the nominativepartitive alternation in particular contexts, e.g. certain predicates take only partitive or only nominative subjects (Metslang 2012), some determiners, when modifying the subject NP, allow only nominative marking (Nemvalts 2000). Below, I broadly summarize the most relevant approaches also used in this study.

Quantitative indefiniteness. Quantitative indefiniteness is one of the main semantic factors that is related to partitive marking of subjects and objects in Finnic languages (Larjavaara 1991). However, in a study on Estonian existential subjects Metslang (2012) has suggested the term quantitative inclusiveness instead of quantitative indefiniteness. By inclusiveness she means (following Lyons 1999) quantitative indefiniteness that takes into account whether "the reference is to the totality of the objects or mass in the context which satisfy the description" (Lyons 1999: 11) and is especially important with plural and mass nouns. The 
notion of inclusiveness also covers uniqueness, i.e. expressions that are definite due to uniqueness are also definite with regard to inclusiveness (Lyons 1999). According to Metslang (2012), Estonian DSM thus makes a distinction between inclusive and non-inclusive usages, i.e. whether all potential referents are included or not. Partitive is used when "the speaker chooses to emphasize the referent's non-inclusive quantity in a particular situation" (Metslang 2014: 194); the nominative is used to mean 'all of the group'. According to Metslang's findings, the nominative is also used when the clause is neutral with respect to inclusiveness. Example (8) above can thus be analyzed either as quantitatively inclusive ('all the chairs were in the kitchen') or neutral with respect to inclusiveness (the speaker does not specify quantity relations). The partitive, in contrast, designates indefinite quantity and emphasizes it. However, it does not necessarily bring the partial meaning with it (Metslang 2012: 160), but rather has the meaning of 'some' or 'type of'.

Qualitative definiteness and information structure. Quantitative definiteness must be kept apart from qualitative definiteness in terms of familiarity or identifiability (see, inter alia Lyons 1999), which is related also to givenness, based on the distinction between discoursegiven and discourse-new information (see, inter alia, Prince (1981) where the notions of discourse-old and discourse-new are based on 'assumed familiarity'). According to Metslang (2014), subjects that are definite with regard to quantitative and qualitative definiteness (inclusive quantity + identifiable) are case-marked with the nominative in affirmative existential clauses and with the partitive in negative existentials.

Definiteness is related to referentiality in general. On the one hand, subjects of existentials are often abstract (9) or even express an event, and are thus low in referentiality hierarchies (see e.g. Bickel 2010). Abstract subjects of existentials tend to occur in the partitive in Estonian (Metslang 2014). On the other hand, even when referring to a concrete entity, subjects of existentials often remain non-specific, thus low in referentiality, especially in the scope of negation, where concrete entities are also typically used non-specifically (10).
(9)
$\begin{array}{ll}\text { mene-l } & \text { pole } \\ \text { some-ADE } & \text { be.CONNEG }\end{array}$
aega
ol-nd-gid
sedavisi (KÄI)
'Some didn't have time.' 
$\begin{array}{rlllll}\text { (10) jaq } & m u & \text { jaoss } & \text { ess } & \text { ole } & \text { luitsa-t (PLV) } \\ \text { and } & \text { I.GEN } & \text { for } & \text { not.PST } & \text { be.CONNEG } & \text { spoon-PRT }\end{array}$

'And for me, there was no spoon.'

Negative existentials (and related constructions) are the most typical context for PSs in Estonian as well as in other Finnic languages, and are also the most systematic context for the partitive-genitive in Lithuanian and certain Slavic languages, e.g. Russian, Polish, Czech (Miestamo 2014). Miestamo particularly emphasizes the functional connection between negation and non-referentiality to explain this phenomenon: partitives typically "refer to a non-individuated mass rather than a clearly delimited entity and they thereby provide a useful form for expressing indefinite non-referential readings." (Miestamo 2014: 82) Decreased referentiality has been discussed in connection with negative existential clauses especially in studies on Russian and other Slavic languages (Partee et al. 2011).

Existential clauses are often called presentational, as their main function is to introduce unidentifiable or inactive referents into the discourse (Lambrecht 1994). Especially in studies of Finnish existentials, it has been argued that existential subjects typically bring new referents into the discourse (more than $75 \%$ of existential subjects refer to new referents, Huumo and Helasvuo 2015) ${ }^{2}$. However, it seems that the situation is different in Estonian: existential constructions, at least with PSs, typically do not introduce new referents in spoken discourse, but only underline the occurrence of the subject referent with respect to certain circumstances. (See section 5.1.)

Holistic interpretation of the situation. In the framework of Cognitive Semantics, Huumo has argued that existentials in Finnish foreground the conceptualizer's external, holistic viewpoint over the event or situation, and as a result, topical partitive subjects do not dominate semantically in the sentence as typical nominative topics do. This can be observed in sentences which express an event where the referents of quantitatively indefinite partitive subjects are semantically distributed over space or time but are interpreted as part of a holistic event. (Huumo 2003).

2 In Finnish linguistics, the term $e-N P$ has recently been used for the only argument in existential and related constructions because of its different behviour compared to prototypical nominative subjects (Helasvuo and Huumo 2010; Huumo and Helasvuo 2015); also Metslang uses this term (2012). 


\section{Estonian dialects and the Corpus of Estonian Dialects}

\subsection{Corpus \& data}

The data are derived from the Corpus of Estonian Dialects (CED), ${ }^{3}$ compiled at the University of Tartu. The CED represents spoken dialects recorded between 1957-1980, and includes dialect interviews from all Estonian dialect areas. The informants have been selected on the basis of classic criteria: they are local people, typically not highly educated, and have not moved around during their lives. The texts in the corpus represent dialect interviews, which often include long monologue passages. The topics of the interviews deal with respondents' personal life, family, lifestyle and working methods in the past, or episodes in their lives.

For this study, I have used morphologically annotated parts of the corpus that were later syntactically parsed with the help of the syntactic parser of Estonian. The parser is based on Constraint Grammar and it was first developed for modern written Estonian, and later adapted to dialects (Lindström and Müürisep 2009). From syntactically parsed texts, partitive subjects were identified. Although the parser works fairly well, it still makes mistakes, especially in detecting clause boundaries. Hence all the texts were checked manually. As manual checking is time-consuming work, I have limited this study to 12 subdialects. Altogether, approximately 220,000 running text words from the corpus were included in the analysis, with 1517 occurrences of PSs.

The subdialects were chosen by the following criteria: 1) at least one subdialect from each main dialect was included; 2) the subdialects are geographically and linguistically distinct from each other; 3 ) from each subdialect, texts from at least 3 different speakers were available.

Figure 1 shows the main Estonian dialect areas and the subdialects included in the quantitative analysis.

$3<$ http://www.keel.ut.ee/et/keelekogud/murdekorpus $>$ 


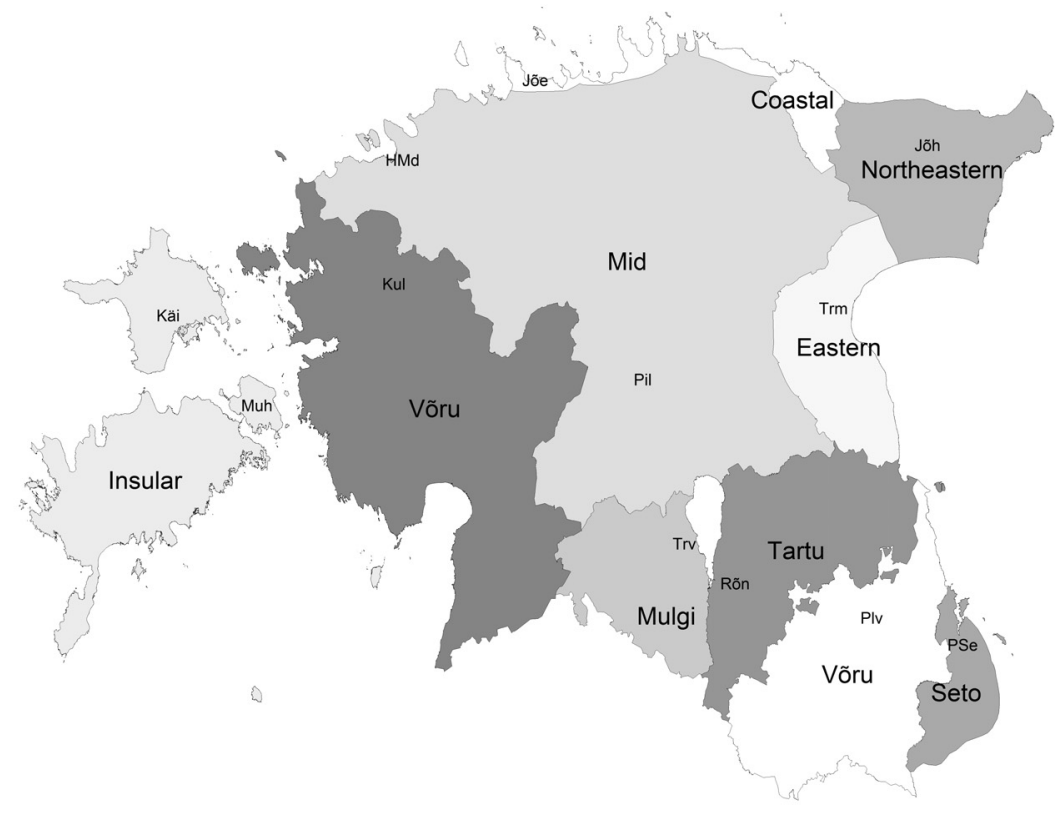

Figure 1. Estonian dialects areas and subdialects included in the study. Map: Kristel Uiboaed.

\subsection{Minor linguistic contacts of dialects}

The subdialects included in the study are found in different contact situations, which may also have some influence on the use of PSs. Old contacts with Baltic languages probably do not have much importance in the syntactic divergence of dialects (or at least their impact is hard to detect). German influence is evident all over Estonia, since Germans owned land and formed an upper class throughout Estonia, from the 13th century until 1918. However, based on previous studies, it is hard to estimate the regularity and intensity of German influence on different Estonian dialects; there is no evidence that German influence has been stronger on some areas than on others. Still, we can infer from geographical and historical facts that German influence has most likely been weaker in the southeastern part of Estonia, e.g., the Seto dialect area, due to intense connections in this area to Russian-speaking Pskov.

Swedish influence is evident in western and coastal Estonian. Swedish settlements in Estonia have been present since the 13th 
century (Juhkam 1992). However, in some areas, the Swedish population was small and rapidly assimilated, while in others, it survived until the Second World War. Therefore, the Swedish influence on Estonian differs considerably across (sub)dialects, being the most evident in the Insular and Western dialects (especially in subdialects spoken on the western coast of Estonia), the North-Western subdialects of the Mid dialect and the Coastal dialect (Juhkam 1998). Among subdialects included in the current analysis, Swedish influence has been reported in Harju-Madise (Juhkam 2012), Jõelähtme (Must 1987) and Käina (Sedrik 1999); but it may also appear in Muhu, which belongs to the Insular dialect. Kullamaa is outside of the Swedish settlement area, but indirect influence is possible there as well. In Harju-Madise, Swedish influence has been attested in subject marking, as the nominative is often used instead of the partitive in the subject position (Juhkam 2012: 504). Similar examples are also found in the Swedish-Estonian contact area belonging to the Western dialect (Juhkam and Sepp 2000) but these subdialects are not included in the study. However, at least modern Swedish has an additional impersonal subject det 'it' in existentials; the 'real' subject is indefinite and occurs in postverbal position (e.g. Det finns citroner $i$ kylskåpet. 'There are lemons in the fridge', lit. 'It can be found lemons in the fridge', Viberg 2010: 129-130); thus the idea that Swedish influence supports nominative marking of existential subjects in the contact area may be somewhat simplistic.

Local contacts with other Finnic languages have taken place especially in eastern and north-Eastern Estonia (mostly Votic but also Ingrian), northern and coastal Estonia (Finnish) and southern Estonia (Livonian). In the eastern part of Estonia, the influence of Votic is attested in pronunciation and morphology as well as in vocabulary, being the most evident in the Eastern (subdialect Torma in this study) and Northeastern and Coastal dialects (Jõhvi in this study) (Pall 1982, Must 1987, Alvre 2000). In Jõhvi, Jõelähtme and Harju-Madise, some Finnish influence can be found as a result of contacts over the Gulf of Finland. Contacts with Livonian have been described in the Mulgi dialect area (incl. Tarvastu) (e.g. Pajusalu 1996); however, Livonian interference is not evident in this area and the Livonian language has now disappeared.

Russian influence is found in all dialect areas as well as in the literary language, due to long-lasting contacts dating back more than 1000 years (Blokland 2009). However, in eastern and South Estonian dialects, the contacts with Russian have been more intensive than in 
other parts of Estonia; most of the Russian loanwords found in dialects have been attested in this area (Must 2000). In my data, the Russian influence is evident in Torma since there have been Russian speakers living in that area since the 17th century, known as Old Believers (see e.g. Čekmonas 2001). A strong Russian influence is also attested in the South Estonian Seto dialect, represented here by the subdialect PõhjaSeto. There have been close religious, cultural, and linguistic contacts between Seto and Russian over a long time period, since Seto is spoken on the border between Estonia and Russia and most of the speakers of Seto also belong to the Orthodox church. Interestingly, the contacts with Russian may have reduced the use of PSs, as has been found in the bilingual Estonian-Russian region in Iisaku (Must 1965).

Among the subdialects selected for the study, Pilistvere represents the North Estonian Mid dialect, which is also the basis for standard Estonian. On the basis of vocabulary, Pilistvere is not clearly connected with other Estonian dialect areas; it has been characterized as an average North Estonian dialect, at least by lexical features (Pajusalu and Krikmann 2000).

Põlva, Rõngu, Tarvastu and Põhja-Seto belong to the South Estonian dialect group, which differs from North Estonian with respect to many phonological, lexical and morphological features. Among South Estonian dialects, Põhja-Seto has many contacts with Russian. The Latvian influence is reported to be strongest in the area that is close to Latvia (Vaba 2011); however, such subdialects are not included in the study. In the overall South Estonian dialect area, the contacts with Latvians have been more intensive than in North Estonian dialects.

The main linguistic contacts of the subdialects included in the study are summarized in Table 1. German influence has not been taken into account because there is no evidence that it has been stronger in some dialect areas than in others. 
Table 1. Estonian subdialects included in the study and their main contact languages.

\begin{tabular}{l|l|l|l} 
Dialect group & Subdialect & Main dialect & Main linguistic contacts \\
\hline $\begin{array}{l}\text { Northeastern- } \\
\text { Coastal) }\end{array}$ & Jõelähtme (JÕE) & Coastal & Swedish, Finnish \\
North & Jõvi (JÕH) & Northeastern & Votic, Finnish, (Ingrian) \\
Estonian & Harju-Madise & Mid & Swedish, (Finnish) \\
& Kullamaa (KUL) & Western & (Swedish?) \\
& Käina (KÄI) & Insular & Swedish, (Finnish) \\
& Muhu (MUH) & Insular & (Swedish) \\
\hline South & Pilistvere (PIL) & Mid & \\
Estonian & Torma (TRM) & Eastern & Russian, Votic \\
& Põlva (PLV) & Võru & (Latvian) \\
& North Seto (PSE) & Seto & Russian, (Latvian) \\
& Rõngu (RÕN) & Tartu & (Latvian) \\
& Tarvastu (TRV) & Mulgi & (Latvian), (Livonian)
\end{tabular}

\section{Dialectal differences}

In this section, I look at the dialect data in order to determine whether there are differences between the dialects in using partitive subjects on a macro level and how the differences are related to the local language contacts described in section 3.2. First I look at the relative frequency of PSs in the subdialects included in the study (4.1). Then, the distribution of negative and affirmative clauses including PS across dialects is examined in order to find out whether some of the dialects prefer PSs mainly in negative clauses.

\subsection{Overall frequency of PSs}

Table 2 presents the overall frequency of partitive subjects in the subdialects under consideration. As the text passages in the corpus were not of equal size, the total number of occurrences of PSs is given in column 2 and the size of the texts (in words) in column 3. In column 4, the frequencies of PSs are normalized per 10,000 words for making comparison easier. 
Table 2. Frequency of PS in subdialects.

\begin{tabular}{l|l|c|c|c} 
& Subdialect & No. of PSs & $\begin{array}{c}\text { No. of } \\
\text { text words }\end{array}$ & $\begin{array}{c}\text { PSs per } \\
10,000 \text { words }\end{array}$ \\
\hline $\begin{array}{l}\text { Northeastern- } \\
\text { Coastal dialects }\end{array}$ & Jõelähtme (JÕE) & 165 & 19,507 & 85 \\
& Jõhvi (JÕH) & 127 & 16,953 & 75 \\
\hline $\begin{array}{l}\text { North Estonian } \\
\text { dialects }\end{array}$ & Harju-Madise & 136 & 18,729 & 73 \\
& (HMD) & & & \\
& Kullamaa (KUL) & 111 & 18,502 & 60 \\
& Käina (KÄI) & 86 & 14,980 & 57 \\
& Muhu (MUH) & 181 & 20,461 & 88 \\
& Pilistvere (PIL) & 134 & 19,721 & 68 \\
& Torma (TRM) & 130 & 19,685 & 66 \\
\hline South Estonian & Põlva (PLV) & 144 & 17,344 & 83 \\
dialects & North Seto (PSE) & 98 & 21,160 & 46 \\
& Rõngu (RÕN) & 95 & 14,116 & 67 \\
& Tarvastu (TRV) & 110 & 18,777 & 59 \\
\hline Total & & 1517 & 219,935 & 69
\end{tabular}

In order to find out whether the differences in Table 1 are statistically significant, I applied a $\chi^{2}$ test to the data. The $\chi^{2}$ test showed statistically significant differences between the analyzed subdialects with $p<0.001$. A pairwise posthoc-test (with Bonferroni corrections) showed that PSE differed significantly from most subdialects, representing a high occurrence of PSs (Jõelähtme, Jõhvi, Muhu, Põlva, $p<0.05$ ). Differences between other dialects were not statistically significant. Thus, the main result is that North Seto uses significantly fewer partitive subjects than the other subdialects in the study. The most interesting is the difference between North Seto and Põlva, since the latter is geographically very close to North Seto. The difference may be a result of Russian influence, which has been strongest in the Seto area, spoken on the southeastern border with Russia. Although the partitive genitive used in North Russian is in certain respects similar to Estonian and Finnic languages (Seržant 2014), its use in affirmatives in Russian dialects is more restricted than in Estonian and is almost extinct in Standard Russian (except for some few verbs with prefixal quantifiers such as pri-byt' 'to increase', Ilja Seržant, p.c.). 
The subdialects where PSs occur most often do not form a geographically compact area. Jõhvi and Jõelähtme, belonging to the NortheasternCoastal dialect group, are characterized as more conservative in many respects; many innovations characteristic of Estonian more globally have not taken place there. In this area, a relatively high frequency of PSs is attested, which could be explained as indicating the preservation of the inherited DSM system. The intensive contacts with Finnish across the Baltic Sea may have had a role in preserving the old DSM. However, Muhu, Põlva and Harju-Madise also show a relatively high frequency of PSs. Among them, Põlva belongs to the Vorru dialect (South Estonian); Muhu belongs to the Insular dialect (North Estonian) and thus may have some Swedish influence; also, Harju-Madise belongs to Mid dialect and shows a strong Swedish influence. According to these results, the influence of Swedish has not had much effect on the overall frequency of PSs; compare the frequency of PS in Käina, Harju-Madise, Jõelähtme and Muhu.

Thus, the differences between the dialects based on overall frequencies of PSs are not as large as expected, and there are no clear regional differences that could be easily explained.

\subsection{PS in affirmative and negative clauses}

In this section I look at the proportions of affirmative and negative clauses containing PSs in subdialects. I expect the results to be correlated with the overall frequency of PSs: the higher the frequency of PSs, the larger the proportion of PSs occurring in affirmative clauses.

From Figure 2 we can see that among the occurrences of PSs in the studied subdialects, North Seto (PSE) also has the highest proportion of negative clauses. So it seems that PSE has lost something in the productivity of use of PS in affirmatives, compared to other subdialects. The highest proportions of affirmative PSs are found in Jõhvi, Jõelähtme and Harju-Madise, where the overall frequency of PSs was higher as well, thus confirming the expectation that a higher frequency of PSs is related to affirmative usages. Muhu and Käina, both representing the Insular dialect, are exceptional: both use PSs more often in negative contexts, but in Käina, the overall frequency of PSs was low, while in Muhu, it was high.

Statistically, the differences between the dialects are not significant; hence the differences between the subdialects are smaller than expected. 


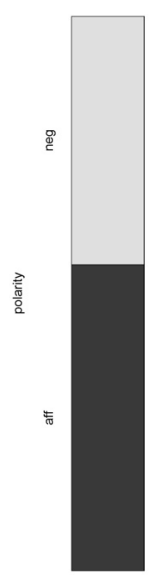

HMD

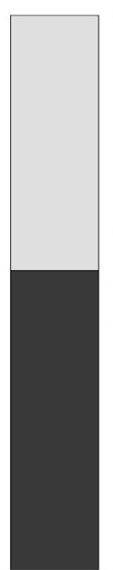

JŌE

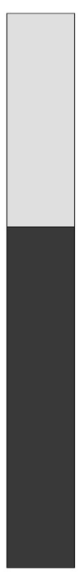

ЈÕH

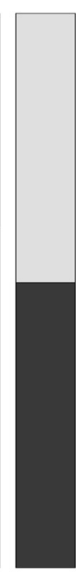

KUL

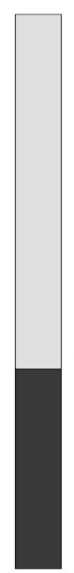

KAI

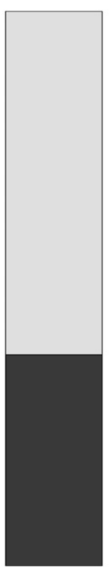

MUH

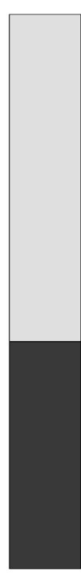

PIL

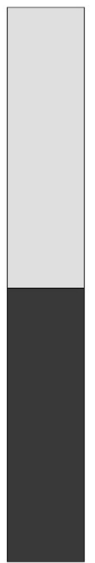

PLV

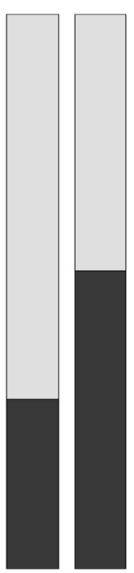

PSE

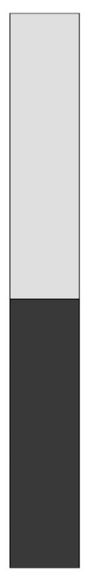

TRM

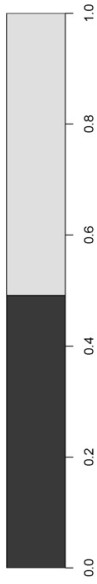

Figure 2. Proportions of affirmatives and negatives in clauses containing PSs. The width of the columns indicates the occurrences of PSs in the data.

\subsection{Morphosyntactic features in determining dialectal differences}

As a next step, I looked at the distribution of various morphosyntactic features that can be identified in each occurrence of PS: polarity (affirmative or negative clause, as in 4.2), occurrence of an external quantifier that does not belong syntactically to the partitive NP (see section 5.2 for more details), and the use of plural or singular (pro) nouns as the PS. The objective is to estimate the general productivity of using PSs: if the subdialects make more use of affirmative clauses with plural PSs without an external quantifier, the subdialect represents more productive use of PSs, characteristic to the inherited system in Finnic languages. If it makes extensive use of singular nouns as PS in negative clauses or plural PSs with external quantifier, the use of PSs is somewhat restricted.

As a method, I use Multiple Correspondence Analysis. The analysis uses the frequency data of the chosen linguistic categories in subdialects. As slightly different amounts of data were available from each subdialect, the data has been normalised to enable reliable comparison. The results can be seen in Figure 3. 


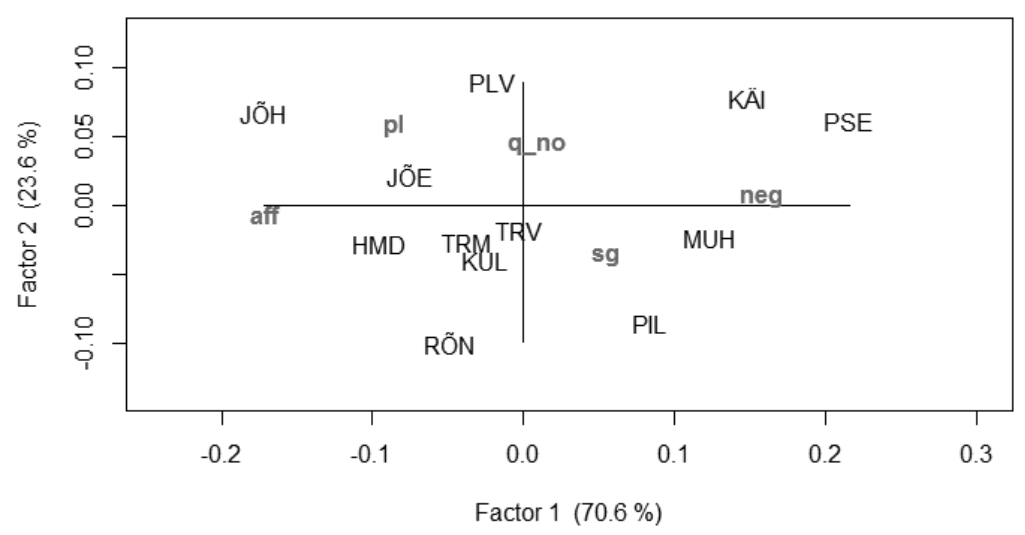

Figure 3. Results of the Multiple Correspondence Analysis.

In Figure 3, the affirmative-negative distinction is represented on the horizontal axis, the use of external quantifier on the vertical axis, and the use of singular or plural referents on the third, imaginary axis. The closer the subdialect is to a linguistic category on the graph, the more characteristic the category is to this subdialect. Thus, the use of negative clauses with PSs is more characteristic to Käina, North Seto, Muhu and Pilistvere, while affirmative contexts are more usual in Jõhvi, Harju-Madise and Jõelähtme (the same appeared already in section 5.2). Põlva and Jõhvi use a lot of plural PSs without external quantifiers hence we may conclude that Põlva and Jõhvi represent more productive use of PS, while, for example, in Rõngu and Pilistvere the use of PS is more often related to the use of an external quantifier. Jõhvi and Jõelähtme use often plural PSs in affirmative clauses, and hence they can be estimated as subdialects with productive use of PSs. Tarvastu, Torma and Kullamaa are, according to this analysis, in the midpoint of the axes; this means that they cannot be distinguished by these features and represent a sort "average".

Thus we can conclude that use of partitive subjects in Estonian is more unified than expected: the differences are small, and by frequency of use of PSs, only North Seto differs from other subdialects. On the other hand, according to the Correspondence Analysis based on some morphosyntactic features, we may estimate that some areas - esp. Jõhvi, Jõelähtme and Põlva, and perhaps also Harju-Madise - show less restricted, i.e. more productive use of PSs than other subdialects. In these subdialects, the overall usage frequency of PSs was also high (see Table 2). In Käina, North Seto, Muhu and Pilistvere, the use of PSs is related to negation, and in Rõngu, to the use of external quantifiers. 


\section{Partitive subjects across constructions}

In this section, I provide an overview of the uses of PSs in my data. I used the Estonian clause type classification as a starting point (Erelt and Metslang 2006), but as the classification is too coarse for data-driven analysis, I distinguished more constructions. The main constructions and their occurrences in negative and affirmative clauses are presented in Table 3. Most of them are discussed in subsequent sections, except event clauses and fixed constructions. Event clauses are discussed later (section 5.3. below) in connection with incremental usages; they differ from other constructions by the verb, designating rather an event than a state (as existentials typically do). Fixed constructions form a vague bundle of fixed usages, used for discourse purposes (11); I do not discuss them in this paper.

Table 3. Constructions using PSs.

\begin{tabular}{l|c|c|c} 
Construction (section) & affirmatives & negatives & Total \\
\hline Existential (5.1) & $327(38 \%)$ & $529(62 \%)$ & 856 \\
\hline Possessive (5.1) & $89(39 \%)$ & $141(61 \%)$ & 230 \\
\hline Experiencer (5.5) & $10(26 \%)$ & $28(74 \%)$ & 38 \\
\hline Quantifier (5.2) & $196(92 \%)$ & $18(8 \%)$ & 214 \\
\hline Weather (5.7) & $13(81 \%)$ & $3(19 \%)$ & 16 \\
\hline Predicative (5.6) & $30(100 \%)$ & 0 & 30 \\
\hline Source-marking (5.4) & $5(33 \%)$ & $10(67 \%)$ & 15 \\
\hline Event (5.3) & $44(65 \%)$ & $24(35 \%)$ & 68 \\
\hline Fixed constructions & $9(18 \%)$ & $41(82 \%)$ & 50 \\
\hline Total & $723(48 \%)$ & $794(52 \%)$ & 1517
\end{tabular}

(11) sõss eij ole midägi (PLV) then not be.CONNEG anything.PRT

'Then it's nothing'

\subsection{PSs in existential and possessive constructions}

In the Estonian linguistic tradition, possessive clauses have been regarded as a separate clause type distinct from existentials, although they are similar to existentials with regard to the basic XVS word order 
and the nominative/partitive alternation in subject marking (Erelt and Metslang 2006). These clause types share many features, including the possibility of using PS, and in actual discourse data, they are often hard to distinguish, for example, if the clause-initial argument is missing or both the locative and the possessor expression co-occur in the same clause. In what follows I treat both clause types as existentials (following previous practice as in Rannut 1964, Nemvalts 2000, Metslang 2012).

Most of the occurrences of PSs in the analyzed part of the corpus (see Table 3) are found in existential constructions that assert or deny the existence of the subject referent in a certain location or time. In spoken discourse, examples that could be characterized as introducing new referents in discourse are rare, although it has been claimed that the main function of existentials is to introduce new referents into the discourse context (Erelt et al. 1993: 15), and existentials are used for that purpose in Finnish as well (Huumo and Helasvuo 2015). However, some examples of new referents can be found, as can be seen from examples (12-13).

Example (12) (a possessive clause) represents the use of PS referring to new referents that were not mentioned in the previous discourse. In this clause, the use of the partitive allows the interpretation that the illnesses are occasional and their amount is indefinite. A similar example is provided in (13), but there the use of the partitive is clearly motivated by quantitative non-inclusiveness - it gives an interpretation that among others there were also some weak young birds. This interpretation is supported by the presence of the particle kahh 'too, also'.
$\begin{array}{lll}\text { mei-l } & \text { umm } & \text { kõgesugudaid'si } \\ \text { we-ADE } & \text { be.3SG } & \text { every kind of.PL. }\end{array}$
hät'ti
eläj-i-l (PLV)
we-ADE be.3Sg every_kind_of.PL.PRT illness.PL.PRT animal-PL-ADE
'our animals have every kind of illnesses/troubles'
(13) sääl ol'
there be. PST.3SG such:PL.PRT
jõvvettuis'i
weak:PL.PRT
poige
kahh (PLV)
too

'There were such weak young birds, too'

For new referents, it is more common to use nominative case marking, and according to my data, this takes place mostly in SV-clauses that are generally not regarded to be existential clauses, as in (14), where the clause-initial nominative subject also triggers verb agreement. 


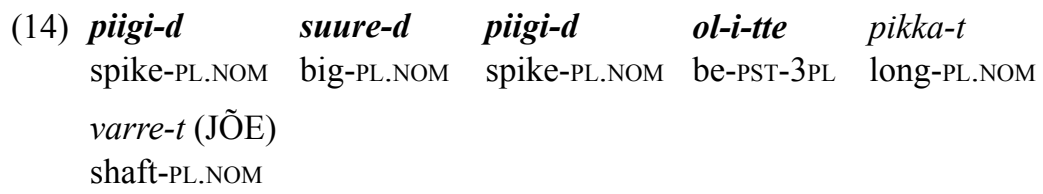

'There were spikes, big spikes, long shafts'

Instead of introducing new referents, PSs are systematically used to re-affirm the existence of discourse-old referents, as in (15-16). However, in these examples the referents of PS are not fully definite, and here rather a 'type of' meaning is obtained. In this case, the 'type' is activated in the discourse, and the PS affirms that there is an indefinite amount of possible referents. In (15), the interviewer has asked whether there are lizards around there, and the interviewee gives an affirmative answer using PS. She also adds an adjective hull 'crazy, bad' to the phrase headed by the pronoun. A similar example is provided in (16), where the interviewer's question was about witches, and the interviewee confirms that there were them, i.e. there were some of this type of people. The use of the partitive may be motivated by the noninclusiveness (indefinite quantity), providing the interpretation 'a few' or 'among many others'.

\begin{tabular}{|c|c|c|c|c|c|}
\hline jaahh & nohh & $n e-i-d$ & ulle & onn & küll (MUH) \\
\hline yeah & PART & these-PL-PRT & crazy.PL.PRT & be. $3 \mathrm{sg}$ & yes \\
\hline
\end{tabular}

(16) A: jahh, kas siin ka mõni nõija värk ol'l vai

'Was there also some witches' stuff here?'
B: siin ol'l-i ne-i-d jahh (RÕN)
here be-PST.3Sg they-PL-PRT yes
'Here were them, yes'

Negative existentials with PS were remarkably more frequent than affirmatives in my data (62\% vs. $38 \%$, see Table 3$)$. Negatives are not generally used to introduce new referents into the discourse. (Miestamo 2014) The negated participants typically remain non-specific (decreased referentiality) as in (17): 
$(17)$

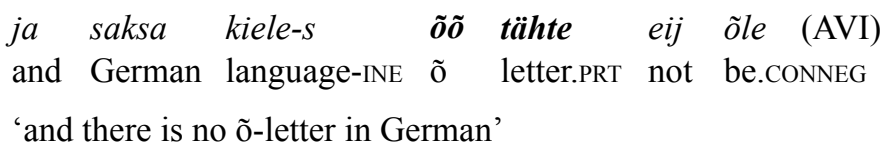

Thus it seems that in spoken Estonian (at least in dialect speech), the partitive is not used for marking qualitative indefiniteness of the subject referent, but mainly quantitative indefiniteness (non-inclusiveness). In Finnish, the partitive marking of plural subjects with a multiplicity of referents is obligatory in existentials; using the nominative instead of the partitive entails a contrastive reading of the verb-final NP, which is also understood as definite. (Huumo and Lindström 2014) In Estonian, on the contrary, nominative marking is neutral and partitive marking provides a non-inclusive reading. These results support the findings of Metslang (2012): the partitive is used to express non-inclusiveness ('some of the group'), and also 'type of' meaning, while the nominative expresses either inclusiveness 'all of the group' or is neutral with respect to inclusiveness. Spoken dialect data, however, prefer an SV-clause with a nominative subject for introducing new referents, and this seems to be a systematic difference between spoken and written Estonian as the existential SV-construction is used in spoken Estonian more widely (Lindström 2011). Dialectal differences were insignificant in my data.

PS is also used regularly with mass nouns marking the existence/ possession of an indefinite amount of a substance or abstract referents expressed with non-count nouns, as in (18) and (19). This usage is central for PSs in general, as such clauses occur quite often. However, such uses also confirm that PSs are not used for introducing central discourse topics: non-count nouns expressing substance or abstract relations do not typically rise to discourse topics; they rather provide background information and are used only locally in the discourse. Discourse backgroundedness has been argued to be one of the typical features of PS/partitive genitive in Circum-Baltic languages (Seržant 2015) and it seems to be a property of Estonian PSs as well.

$\begin{array}{llll}\text { siiss } & \text { ol-i } & \text { karttul-t } & k a h \quad(\mathrm{RO} N) \\ \text { then } & \text { be-PST.3SG } & \text { potato-PRT } & \text { too }\end{array}$

'then there were potatoes too'

ta-lle ikke jää- $b \quad$ vana-d maitse-t juure (PIL)
it-ALL PART remain-3SG old-PRT taste-PRT to
'there remains some old taste to it'


The obligatory use of PSs in negation has been seen as one of the most important features of existentials, and it is often regarded as the main formal criterion for defining existentials in Estonian (Nemvalts 2000). In negative existentials, PSs are used most systematically in all the observed dialects. However, in western subdialects I also found some occasional usages of the nominative in negated existential clauses. In the Insular dialect the nominative subject was used in negative existentials in a construction containing the negation particle mitte 'not'; the particle marks the focus of the negation, and thus the whole clause still has an existential meaning; also the existential verb ole- is used (20).

(20) aga mette üks riideilp ole sehes (MUH)
but not one cloth_bit.NOM be.CONNEG in
'but there wasn't a single piece of cloth in it'

Several examples where the nominative is used in negative existentials have also been attested earlier in Harju-Madise (Juhkam 2012: 504-505), in my data (21). They have been explained by the influence of Swedish, where the subject is always in the nominative (Juhkam 2012).

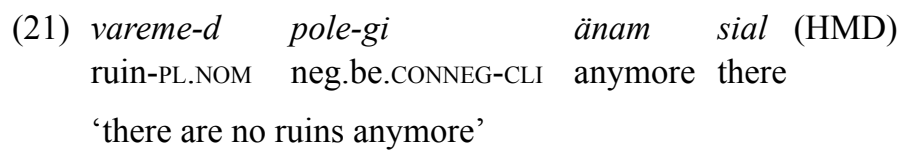

Most of the examples of PS analyzed in this section so far lack something in referentiality. Singular count nouns occur as PSs mainly in negated clauses, but under negation they are referentially non-specific (not referring to a referent); also abstract or mass nouns as PSs show decreased referentiality. In general, most PSs refer to inanimates and non-humans.

However, in Estonian, the use of the partitive of negation has extended to specific, highly topical animate participants (such as discourse participants, even the speaker). In such instances, the PS is specific and its referent is definite both quantitatively and qualitatively. The function of such a clause is to deny the presence of the participant in a certain location or in certain circumstances. In (22) and (23), the PS refers to an animate, specific and topical referent in the narrative passages; in (24) the PS refers to the speaker in the narrative passage. 
(22) ko immä tarõ-hh olõ õss (PSE)

when mother.PRT room-INE be.CONNEG not.PST

'when mother wasn't in the room'

(23) se-da in'imes-t änam eij ela (PIL)

this-PRT person-PRT anymore not live.CONNEG

'This person does not live anymore'

$\begin{array}{llllll}n i \quad \text { minno } & \text { hinnäs-t } & \text { mann } & \text { õss } & \text { olo } & \text { (PSE) } \\ \text { and I.PRT } & \text { self-PRT } & \text { by } & \text { not.PST } & \text { be.CONNEG } \\ \text { 'I myself wasn't there' } & & & \end{array}$

Such uses are more common and widespread in Estonian than in Finnish, especially in instances where the subject is a speech act participant referred to by a personal pronoun (Huumo and Lindström 2014). Similar usages have been observed in Northern Russian as well, using the partitive genitive instead of the nominative (Seržant 2014). Seržant explains these usages as expansions of the non-referentiality reading from the NP to the whole situation. (Seržant 2014) Semantically, it can also be explained by the holistic viewpoint over the event (Huumo 2003), i.e. the event is conceptualized from an external viewpoint and not from the viewpoint of the topical participant. As a result, the agenthood of the topical participant is reduced in comparison to nominativemarked subjects.

Interestingly, there seem to be some differences in the distribution of specific, topical, singular PSs among the dialects: most of my examples come from South Estonian, especially from North Seto, and Eastern, i.e. dialects that have had more contacts with Russian while in the Northeastern and Coastal dialects that generally use PSs more often, such examples are rare or even missing in my data. Thus the contacts with Russian could serve as a possible explanation here. However, the overall number of such occurrences is too low to draw more substantial conclusions about dialectal differences.

\subsection{The quantifier construction}

A large number of clauses in my data represent usages that assert something about the quantity of the subject referent as in (27). The construction is clearly connected to the use of quantifiers in general: 
Estonian quantifiers (incl. numerals) typically take a nominal complement in the partitive, together forming a phrase that is called a quantifier phrase in Estonian grammars (25-26). (Erelt et al. 1993) The quantifier phrase may occur in subject position as well as in other positions where NPs typically occur. Note that numerals take a nominal in the singular (25) and quantifier adverbs take a nominal in the plural (26). In a quantifier phrase, the quantifier (a numeral, adverb, or noun) always precedes the complement (a noun).

Kolm mees-t $\begin{aligned} & \text { oota-si-d bussi. } \\ & \text { three man-SG.PRT }\end{aligned}$ wait-PST-3PL bus.PRT
'Three men were waiting for a bus.'

Palju mehi oota-s bussi.
lot man.PL.PRT wait-PST.3SG bus.PRT
'A lot of men were waiting for a bus.'

The construction I am calling the quantifier construction is different from (25) and (26) because the quantifier is not syntactically connected to the subject but occurs somewhere else in the clause, typically in clause-final, adverbial position (27). The occurrence of the quantifier forces the partitive marking of the subject, and the whole construction expresses the quantity of the subject referent as the most important information. The construction is very frequent in the corpus data, so it can be assumed that it is a systematic way of using PSs. In Estonian grammars, the occurrence of the quantifier apart from the noun has been described as a detached quantifier phrase and explained mainly by way of information structure (Erelt et al. 1993).

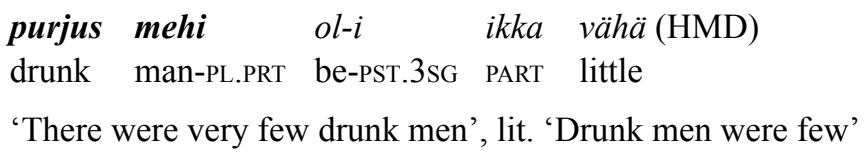

However, there are systematic differences compared to the regular quantifier phrase in Estonian. First, the quantifier used in the construction does not always have a grammatically acceptable counterpart construction where it is adjacent to the partitive-marked noun (28), thus it is not just a question of detaching a unified phrase into two parts. Second, the construction is regularly used with personal pronouns: PSs in (28) and (29) as personal pronouns cannot typically be used in quantifier phrases. 


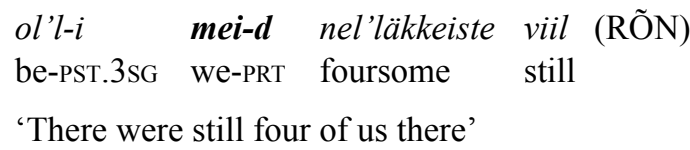

The third difference from regular quantifier phrases concerns the use of numerals: in quantifier phrases, numerals take a singular complement, but in this quantifier construction with separate PS, the complement (i.e. subject of the clause) is in plural (29).

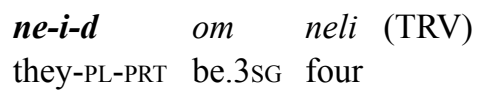

'There are four of them', lit. 'them is four'

Thus, examples (28-29) in particular indicate that the construction is problematic with respect to regular quantifier phrases and should be analysed as a separate construction. In the Finnish tradition, this construction has been called a quantifier clause (kvanttorilause) (Hakulinen and Karlsson 1979: 99) where the clause-initial partitive NP is analyzed as the subject of an intransitive clause (and the object in a transitive clause) (Hakulinen et al. 2004). The quantifier clause is similar to an existential clause (in addition to the use of PS) as it uses existential verbs (mostly olema 'be'). Note that the same construction works in a similar way in Russian: the noun and the quantifier may occur separately (e. g. on different sides of the verb), and the noun that is split from a paucal numeral must be genitive plural, not singular (Timberlake 2004: 297).

The quantifier construction is extremely common in corpus data and often uses pronouns as PSs, thus increasing the number of pronoun PSs in the overall data. Unlike most of the other constructions, it is used mainly in affirmative clauses (see Table 3 ). There are no statistically significant differences between dialects in the use of the quantifier construction but according to the Multiple Correspondence Analysis (section 4.3) it is more characteristic to Rõngu and Pilistvere than to other analysed subdialects.

\subsection{From quantificational to incremental reading}

Certain time adverbials may also have a quantifying effect, expressing the existence/persistence of the subject referent over a longer 
period. In (30), the PS is a pronoun (anaphorically used demonstrative too 'that') that expresses the situation described earlier in the discourse, and the clause-final adverbial expresses the repetition or duration of the situation over a long time. Similarly in (31), the persistence of the situation over a long time is expressed.

$$
\begin{aligned}
& \text { To-da ol'l-i } \begin{array}{l}
\text { üttelugu (RÕN) } \\
\text { this-PRT be-PST.3SG all_the_time }
\end{array} \\
& \text { 'it happened all the time' }
\end{aligned}
$$

\section{(31) niigauwa kui se-da jää-d ol-i (JÕE) as_long as this-PRT ice-PRT be-PST.3sG 'as long as there was some ice'}

With plural referents, a similar effect occurs. In (32), the PS (neid 'these-PRT') refers to boats; the adverbial is the same as in the previous example (30), meaning 'all the time'. The whole clause, however, does not say that the same boats capsized all the time, but the event of capsizing happened often. Thus, although the event was repeated over some time, the partitive marking of the subject expresses the 'some of the group' meaning (i.e. the PS is quantitatively indefinite, non-inclusive). A similar example is provided in (33a); here, the pronoun refers to Romas. Again, the partitive marking indicates that not all the Romas were there every autumn, but only some of them. Nominative marking, however, would be ambiguous as to whether the composition of the group of Romas the speaker is talking about was the same every autumn or not (33b).

(32) eks

$$
\begin{array}{lllll}
\text { eks } & \boldsymbol{n} \boldsymbol{e}-\boldsymbol{i}-\boldsymbol{d} & \text { on } & \text { ühtelugu } & \text { kumma-nd (JÕE) } \\
\text { PART } & \text { they-PL-PRT } & \text { be.3SG } & \text { all_the_time capsize-PST.PTCL }
\end{array}
$$

'they capsized all the time'
a. eks nä-i-d käi-s
ennemast egä sügis (TRM)
PART they-PL-PRT
go-PST.3SG earlier
every autumn

'(some of) them used to come here every autumn'
b. eks na-d käi-sid ennemast egä sügis PART they-PL.NOM go-PST.3PL earlier every autumn 'they came here earlier every autumn'


A similar distributive usage is observed with spatial adverbials. In (34), the pronoun neid ('them') refers to the people whose surname is Klaama. The whole passage clarifies where they lived, and the last clause summarises that they live in many places. Using the nominative instead of the partitive would give the interpretation that the same individuals live everywhere, while the partitive indicates that the group was distributed over the space.

$\begin{array}{llllll}\begin{array}{l}\text { ne-i-d } \\ \text { they-PL-PRT }\end{array} \text { be.3SG } & \text { kaugemall } & \text { juba } & \text { Kolgass jaa ja } \\ \text { farther } & \text { already } & \text { Kolga-INE and and } \\ \text { siin Nieme-s } & \text { ol-i } & j a & & \\ \text { here Nieme-INE } & \text { be-PST.3SG } & \text { and } \\ \text { ne-id } & \text { onn } & \text { mitme-s } & \text { puol jahh(JÕE) } \\ \text { they-PL-PRT } & \text { be.3SG many-INE } & \text { side yes }\end{array}$

'(some of) them are farther even in Kolga and here in Nieme and they are in many places'

Similar usages in Finnish have been discussed by Huumo (2001, 2003). He calls this usage incremental, following the notion of incremental theme by (Dowty 1991): it is a "participant whose part-whole relations are mapped onto the temporal part-whole relations of the event as a whole" (Huumo 2003). In these examples, PS expresses the distribution of the subject referent over space or time, i.e. either distributively or incrementally. This effect is observable in existential constructions in Finnish that code a situation "from an external viewpoint" (Huumo 2003), i.e. as a holistic event/situation.

\subsection{The source-marking construction}

A source-marking construction is an intransitive construction that expresses the change of state of the participant. The participant whose change is expressed is designated by an elative-case phrase (source), and its final state is marked with either the nominative or partitive. The nominative or partitive constituent is grammatically a subject of the clause, and the whole clause is similar to existentials as it allows case alternation and basic XVS word order. (Erelt 2005) Similarly to existential and possessive clauses, the partitive is obligatory in negative clauses, and the nominative dominates in affirmative clauses. 
In the corpus data, source-marking clauses are rare; in my sample, only 15 examples represent this construction (35).
nende-st $s a-i$
ikka kaptene-isi (HMD)
they-ela
become-PST.3SG PART
captain-PL.PRT

'Some of them became captains'

In affirmatives, the PS is used when the participant involved is distributable, in (35) it is in the plural. In (35), the partitive marking stresses the non-inclusive 'some' meaning: only some of the boys probably became captains (and not all of them); otherwise, the nominative would be used (36).
nende-st $\quad$ sa-i-d
ikka kapteni-d
they-ELA become-PST-3PL PART captain-PL.NOM
'They became captains'

Some of my examples are fuzzy between intransitive and transitive resultatives with zero persons (e.g. the actor is a generalized, unexpressed argument), and often the participant whose state is expressed is an inanimate referent - these features make the interpretation complicated. In (37), it is hard to say whether the clause-final constituent is a subject or object; the verb saama 'get, become' is polysemous and allows both transitive and intransitive usages and thus does not facilitate the interpretation.

$$
\begin{aligned}
& \text { et ei saa tuu-st midägi (PLV) } \\
& \text { that not get/become.CONNEG that-ELA anything.PRT } \\
& \text { '[one] does not get anything from that' / 'it will become nothing' }
\end{aligned}
$$

Note that in my data, only one clause occurred with plural PS in affirmative source-marking resultatives (35). In Finnish, the use of PS (e-NP) is more systematic than in Estonian, especially with plural referents (Huumo and Helasvuo 2015: 35). The source-marking construction, unlike existentials, does not assert the existence of the subject referent but rather the final state of the referent of the elative argument. Similarly, negation does not deny the existence of the person/ object involved (as in existential and possessive constructions) but says that the final state is not reached. 


\subsection{Experiencer constructions}

Estonian has a wide range of experiencer constructions where the marking of the two participants - the experiencer and the stimulus varies largely according to the control or affectedness of the experiencer in the event (Metslang and Erelt 2008, Lindström 2013). Experiencer constructions where PSs may occur in Estonian are similar to either existential or possessive clauses and are based on the same schema: in the most prototypical case, the experiencer appears in clause-initial position and is marked as a possessor (case-marked with the adessive); the stimulus occurs in clause-final position and allows nominative / partitive alternation; the predicate has a general existential meaning. Thus the distinction between the possessor and experiencer is subtle and it depends mainly on the semantics of the stimulus/possessee, e.g. (38) and (39) express emotions and thus are clearly experiencer constructions (although in (39) the experiencer is not expressed), while in (40) the interpretation is closer to possessive clauses. In all of them, abstract nouns occur as PSs. In affirmative experiencer clauses, the partitive marking of the subject is rare (38); typically the nominative is used there. However, it is not possible to draw substantial conclusions here because these types of experiential clauses are rare in the dialect corpus.

$$
\begin{array}{llllll}
\text { aga } & \text { siis } & \text { küll } & \text { ol-i } & \text { mei-l } & \text { rõ } \tilde{\boldsymbol{m}} \boldsymbol{m} \text { (PIL) } \\
\text { but then } & \text { PART } & \text { be-PST.3SG } & \text { we-ADE } & \text { joy.PRT }
\end{array}
$$

'and then we had a lot of joy'

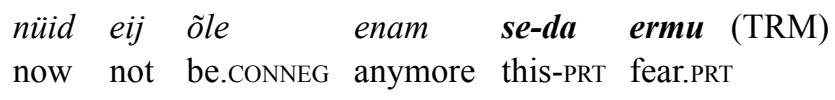

'now we don't have this fear anymore'

(40) ja kelle-l jöudu omm (TRV)

and who-ADE strength.PRT be.3sG

'and who have strength'

In dialect data, there is a frequently occurring construction expressing remembering, in which PSs can be used. Here, the experiencer is marked as a possessor (appearing in the adessive or allative case), and the stimulus is syntactically a subject, allowing partitive/ nominative alternation. The predicate is either meeles olema 'remember, lit. be in mind' that takes an adessive experiencer (41) or meelde tulema 
'remember, lit. come to mind' taking adessive or allative experiencer (42). There is more variation within these constructions; however, most of my examples follow these two patterns.
$\begin{array}{ll}m u-l l & \text { õle } \\ \text { I-ADE be.CON }\end{array}$
miele-s enämb
$n e-i-d$
nime-sid (JÕH)
I-ADE be.CONNEG mind-INE anymore these-PL-PRT name-PL.PRT

'I don't remember these names anymore'
vat mu-ll ei tul-d
se-da meele (PIL)
PART I-ADE not come-PST.PTCL this-PRT mind.ILL

'I couldn't remember it; it didn't come to my mind'

The two constructions are also similar to existential and possessive clauses in that the partitive expressing a stimulus is used mostly in negation, as in (41) and (42) above. As the stimulus is semantically abstract and represents decreased referentiality, partitive marking is also expected in affirmatives. However, the constructions exhibit remarkable variation in using either nominative or partitive marking of the subject. I conducted an analysis over all the dialect data in order to find possible dialectal differences; the results are presented in Table 4.

Table 4. Distribution of nominative and partitive subjects in experiencer constructions expressing remembering (meelde tulema, meeles olema 'remember').

\begin{tabular}{l|r|r|r|r|c}
\multirow{2}{*}{ Dialect } & \multicolumn{2}{|c|}{ affirmative } & \multicolumn{2}{c|}{ negative } & \multirow{2}{*}{ Total } \\
\cline { 2 - 5 } & nom & part & nom & part & \\
\hline Eastern & 2 & 1 & 2 & 2 & 7 \\
\hline Mid & 12 & 2 & 9 & 14 & 37 \\
\hline Northeastern & 7 & 2 & 3 & 3 & 15 \\
\hline Western & 13 & 1 & 0 & 11 & 25 \\
\hline Mulgi & 3 & 0 & 0 & 2 & 5 \\
\hline Coastal & 3 & 2 & 2 & 3 & 10 \\
\hline Insular & 11 & 2 & 6 & 10 & 29 \\
\hline Seto & 3 & 2 & 1 & 8 & 14 \\
\hline Tartu & 11 & 5 & 1 & 4 & 21 \\
\hline Võru & 8 & 3 & 0 & 8 & 19 \\
\hline Total & 73 & 20 & 24 & 65 & 182
\end{tabular}


As can be seen from Table 4, there is considerable cross-dialect variation in the case marking of the stimulus-subject. The nominative dominates in affirmative clauses ( $78 \%$ of affirmatives have nominative subjects), but is often used in negated clauses as well (27\%, ex. 43$)$. The nominative subject in negated clauses is more characteristic of North Estonian dialects (Eastern, Mid, Northeastern, Coastal, Insular dialects), while it is not very common in South Estonian dialects and the Western dialect. The partitive is more strongly related to negative clauses as in (41), (42), but also occurs in affirmatives in all dialects (except Mulgi in my data), ex. (44), (45). However, the number of occurrences is too low to make substantial inferences about dialectal differences; what can be observed from this data is the tendency towards nominative marking of the subject.

$$
\begin{array}{lllll}
e i \quad \text { nie-d } & \text { nime-d } & \text { kõik änam miele-s põle (Mid) } \\
\text { not these-PL.NOM name-PL.NOM all anymore } & \text { mind-INE be.NEG } \\
\text { 'I don't remember all these names anymore' }
\end{array}
$$

(44) tuu-d omm mu-ll meele-hh et... (PSE)

this-PRT be.3SG I-ADE mind-INE that

'I remember that'

(45)

$\begin{aligned} & m u-l l \\ & \text { se-tä } \\ & \text { I-ADE this-PRT also mind-INE }\end{aligned}$
'I still remember that'

\subsection{The predicative construction}

Estonian predicative clauses are intransitive clauses that have a copula olema 'be' and a predicate complement. The complement appears in the nominative and agrees in number with the subject. Partitive marking of the complement is possible, but it is very restricted. (Erelt et al. 1993: 58-59) The prototypical predicative clause has a nominative subject, and the whole clause characterises the subject referent (46).

$\begin{array}{lll}\text { Jala-d } & \text { ol-i-d } & \text { märja- } d . \\ \text { leg-PL.NOM } & \text { be-PST-3PL } & \text { wet-PL.NOM } \\ \text { SUBJ } & & \text { PRED.COMPL. }\end{array}$

'The legs were wet.' 
As becomes apparent in the data, PS is also possible in predicative constructions. In this case, the predicate complement appears in the partitive, as in (47-49).

$\begin{array}{llll}\boldsymbol{n a} \ddot{\boldsymbol{a}} \boldsymbol{i}-\boldsymbol{d} & \text { no } & \text { ol } & \text { kõgetaolis' } i \text { (PLV) } \\ \text { they-PL-PRT } & \text { PART } & \text { be.PST.3SG } & \text { all_kind.PL.PRT }\end{array}$

'They were of all kinds'

(48) Kardul-d ol-i mitmedsugu sortti-si (HMD)

potato-PRT be-PST.3SG various.PRT sort-PL.PRT

'Potatoes were of various sorts'

(49) ne-i-d ôl'-i siin iga sel'tsi(.)

they-PL-PRT be-PST.3SG here every sort.PRT

suuri ja vek'ke-sid (AVI)

big.PL.PRT and small-PL.PRT

'They were of various sorts, big and small ones'

Such clauses are interpreted in Estonian linguistics as a subtype of existential clauses with marked information structure since the verb has an existential meaning (Erelt et al. 1993: 56), i.e. as detached phrases, similarly to quantifier constructions (section 5.2). Unlike typical existentials, the existence of the referent of the PS is presupposed, and the assertion concerns only its type(s).

Here again the partitive marking of the subject expresses the indefinite quantity of the referent even with definite pronouns, as in (47) and (49). The type specification, also case-marked with the partitive, has a general meaning ('every kind of') or offers at least two alternatives. The construction cannot be used with more specific predicate complements, e.g. example (46) cannot be used with a partitive subject and partitive predicative (50a), but it is possible if the predicate complement has an alternative (50b), at least in Standard Estonian. The whole construction can thus be interpreted distributively, i.e. some items in the group of subject referents have only some properties expressed by the predicate complement, and not all the subject referents have all these properties.
a. *Jalgu ol-i märgi. leg.PL.PRT be-PST.3SG wet.PL.PRT
'Some of the legs were wet.' 
b. Jalgu ol-i märgi ja kuivi. leg.PL.PRT be-PST.3SG wet.PL.PRT and dry-PL.PRT

'Some of the legs were wet and some of the legs were dry' / 'There were wet and dry legs'

Note that in my data, the construction is used only in affirmative clauses, distinguishing it from typical existentials (and other previously analyzed constructions) where negative clauses dominate. The construction is more characteristic to North-Estonian, with only occasional examples attested in South-Estonian subdialects.

\subsection{Weather expressions}

Subjects of meteorological predicates, if expressed at all, are nonreferential, non-topical, indefinite and non-agentive (Eriksen, Kittilä and Kolehmainen 2015). In Estonian and other Baltic-Finnic languages, some weather expressions occur systematically with PS (Hakanen 2001), especially in expressions with the meaning 'it is raining', 'it is snowing', as well as 'it [wind] is blowing' in my data. Weather expressions show remarkable variation in the case marking (partitive or nominative) of the subject argument.

The most typical predicate taking PSs is sadama (51), which is a verb used mainly in constructions describing rain and snow; in addition to weather expressions, it has the meaning 'fall'. Other meteorological predicates with PSs have more general meaning: tulema 'come' (52) or olema 'be' (53). Among these, sadama is an old stem that expresses snowing and raining in all Baltic-Finnic languages; it is an inherited stem reconstructed back at least to the Proto-Finnic-Sami period (Metsmägi, Sedrik and Soosaar 2012).

Also the verb tulema 'come' occurs frequently in weather expressions. The same predicate 'come' is used in weather constructions also in Russian and Finnish. In Russian it is used with a nominative subject (Russian dozhd' idet 'it is raining', lit. 'rain comes'); therefore we may also expect that with this verb, a nominative subject is preferred also in some Estonian dialects. The tendency has been attested in the Karelian Valdai dialect, which has been under strong influence from Russian. (Leppik 1962) 
(51) kerge-d lun-d sada-s (TRM)

light-PRT snow-PRT fall-PST.3sG

'A light snow fell'

(52) tule-b iga pääv vihma (JÕE)

come-3SG every day rain.PRT

'It is raining every day'

(53) külma midagi ei ol-n (HMD)

cold.PRT anything.PRT not be-PST.PTCL

'It wasn't cold'

Since the corresponding construction in Russian uses nominative subjects, we might expect language contact to provide at least one reason for using the nominative. However, the picture is more complicated. I conducted a separate analysis on the dialect corpus to find the distribution of nominative and partitive subject marking in expressions of 'raining'. As can be seen from Table 5, with all verbs the subject appears more often in the partitive than in the nominative. The nominative occurs more often with tulema than with the other two verbs, but the difference is negligible.

Table 5. Distribution of partitive and nominative subjects with predicates expressing rain.

\begin{tabular}{l|c|c|c} 
Verb & Nominative & Partitive & Total \\
\hline olema 'be' & 3 & 8 & 11 \\
\hline sadama 'fall' & 7 & 23 & 30 \\
\hline tulema 'come' & 10 & 20 & 30
\end{tabular}

When looking at the distribution of partitive and nominative marking of vihm 'rain' across the dialects, it appears that the partitive dominates in the Western and Insular dialects, i.e. in the dialects that have had less contact with Russian, while in eastern dialects (Northeastern, Eastern, Seto, Tartu, Võru) the nominative and partitive are distributed more equally. Thus, some of the variation may be caused by contacts with Russian. 


\subsection{Indefinite pronouns as PSs}

A number of PS usages occur as indefinite pronouns keegi 'someone, no one' (PRT kedagi) and miski 'something, nothing' (PRT midagi). The choice of the pronoun depends on the animacy of the referent, but not on polarity, as can be seen from the translations. The use of indefinite pronouns is typical for existential and possessive clauses. Indefinite pronouns as PS occur mostly in negative clauses, as in (55), but sometimes also in affirmatives (56).

$\begin{array}{lll}\text { pole } & \text { änam } & \text { midagid (KÄI) } \\ \text { be.NEG } & \text { anymore } & \text { anything.PRT }\end{array}$

'Nothing is left', 'there is nothing anymore'

(56)

$\begin{array}{lll}i k k i & \text { midägi } & \text { oll-i }(\mathrm{TRV}) \\ \text { PART } & \text { something.PRT } & \text { be-PST.3SG }\end{array}$

'There still was something'

However, the use of indefinite pronoun PS seems to be wider than with other types of PS, i.e. it may occur in contexts where the PS usually does not occur. In (57), the verb is tulema 'come', which is complemented with a supine of the transitive verb kaema 'see, look'. Together they designate a single event, and as the second verb is transitive, the whole construction has obtained a transitive meaning. Hence the use of the partitive subject is normally impossible: it would be interpreted as the object of the second verb, and not as the subject of the whole construction. However, in (57) the object of the second verb is not overtly expressed ('me', as becomes clear from the preceding context), and the indefinite pronoun is a PS.

$$
\begin{array}{lllllll}
e i & \text { tule } & \text { ap } & \text { kedägi } & \text { kae-ma } & \text { kahh } & \text { (PLV) } \\
\text { not } & \text { come.CONNEG } & \text { anymore } & \text { anybody.PRT } & \text { see-SUP } & \text { PART } &
\end{array}
$$

'Nobody comes to see [me] anymore'

In example (58), a single transitive verb is used, but again it has been used intransitively.

$\begin{array}{lll}\text { midäge } & \text { avida } & \text { oss (PSE) } \\ \text { Nothing.PRT help.CONNEG not.PST } & \\ \text { 'Nothing helped' } & \end{array}$


A similar phenomenon has been attested in Russian. The Russian negative pronouns nikto and ničto in genitive form are used as subjects with a broader range of predicates than other argument expressions: in addition to existential predicates, they also appear with intransitives and semitransitives that otherwise wouldn't take genitive subjects. (Timberlake 2004: 307) Thus it could be a contact-induced phenomenon, although it is not clear which is the source language and which is the target language. Such usages can be found in Standard Estonian as well.

\section{Conclusions}

The use of partitive subjects in Estonian as well as in other BalticFinnic languages is related to alternation in subject marking in Eastern Circum-Baltic languages. The alternation in Estonian is conditioned by more or less the same factors as in the surrounding languages, concerning mainly quantitative indefiniteness, negation, and decreased referentiality.

As the main result of the study, it can be concluded that the use of PSs in Estonian dialects is relatively uniform. This becomes clear when looking at quantitative data. Although sometimes the use of the nominative has widened in contact situations with Estonian Swedish (examples provided in Juhkam 2012, Juhkam and Sepp 2000), this does not affect quantitative data: subdialects that are spoken in the contact area with Swedish (mainly Harju-Madise, Käina, but also Jõelähtme, Muhu) do not show a noticeably reduced number of PSs, with only Käina showing a lower than average occurrence of PSs. Thus, such occasional usages have not affected the whole system. This becomes even more clear when we look at the use of PSs in different constructions across dialects: all the constructions with PSs described in the paper were found in all subdialects (except the predicative construction that was less used in South-Estonian and was missing in North Seto, Tarvastu and Muhu).

The only area that clearly differs from the others is North Seto, a subdialect spoken on the border between Estonia and Russia, with longlasting intensive contacts with Russian. Compared to other subdialects, North Seto uses fewer PSs in general and especially in affirmatives. As the partitive-genitive is used in Russian existentials most systematically in negative clauses, but is reduced in affirmatives, the impact of Russian on North Seto seems likely. 
To sum up, partitive marking of subjects is an old feature in Estonian as well as in other Baltic-Finnic languages, and this may be a reason why the differences between the dialects are not significant in the quantitative analysis: all the dialects make use of PSs; there are no areas where the PS is absent; the differences may appear in minor patterns but not on a general level. Analysis of co-occurring morphosyntactic features (polarity, number, occurrence of external quantifiers) revealed that, especially in Jõhvi, Jõelähtme and Põlva, but perhaps also HarjuMadise, the use of PSs can be characterised as more productive than in other subdialects, where the use of PSs is more often related to negation (North Seto, Käina) or use of external quantifiers (Rõngu).

Estonian partitive subjects are not restricted only to existential and possessive clauses, as is usually claimed, but rather are used in a wide range of constructions. Nevertheless, existentials clearly form the biggest group where PSs occur.

Partitive marking is tightly related to negative existentials and related constructions, although some constructions (especially experiencer constructions and weather expressions) also use the nominative in negated clauses. Under the scope of negation, PS is typically non-referential even in referring to singular count nouns. Nevertheless, a small amount of quantitatively and qualitatively definite usages in negative existentials were attested in my data; these come mainly from South-Estonian and Eastern dialects, i.e. dialects that have had more contact with Russian, but occasional examples from western dialects attest that such usages are not restricted only to eastern dialects.

In affirmative clauses, the PS occurs in a wide range of constructions. However, in the existential construction it typically does not refer to new referents in the discourse but rather affirms the existence of already introduced referents. Thus, in Estonian, PS is not used for information structuring purposes, and even canonical existential clauses are not used for this purpose in spoken discourse.

In affirmatives, the use of the partitive is related mainly to quantitative indefiniteness. Although the PSs are typically qualitatively definite (already mentioned in the ongoing discourse), there is something open in the distribution of referents in the event or state that is expressed by the clause. In quantifier constructions, the quantity of involved referents is expressed ('many', 'a few', exact number, etc.); this pattern is widened to existentials and possessives where the use of PS often provides the interpretation 'a few' or 'among many others'. In incremental usages, the unbalanced distribution of referents over the 
time or location is clear (only some part of the group was involved in certain temporal or locational points); similar usages are evident also in predicative clauses and affirmative source-marking resultatives with plural referents.

The role of reduced referentiality appears clearly in negated clauses, as typically even reference to concrete objects in the scope of negation remains unspecific and is thus decreased. According to Miestamo, there is a functional connection between non-referentiality and negation and therefore the partitive (as typically referring to a non-individuated mass) is a useful marker for such relations (Miestamo 2014).

Generally, it seems that the dialect data confirms the findings of previous studies on Estonian indicating that negation is the most powerful factor in conditioning the partitive-nominative alternation. Negation explains $52 \%$ of the usages of PSs in my data. As it is also the main factor in other languages of the area (Koptjevskaja-Tamm and Wälchli 2001: 656-660), this result is expected. In comparison to Finnish, it seems that across various constructions, Estonian PS is more often related to negation than in Finnish, and PS is less productive in affirmatives in Estonian.

\title{
Acknowledgements
}

This study was supported by the Estonian Research Council (project PUT90 "Estonian Dialect syntax") and by the (European Union) European Regional Development Fund (Centre of Excellence in Estonian Studies). I am grateful to Ilja Seržant, Tuomas Huumo and Helen Plado for commenting previous versions of the paper. All possible mistakes are, of course, my own.

\author{
Address \\ Liina Lindström \\ Institute of Estonian and General Linguistics \\ University of Tartu \\ Jakobi 2 \\ Tartu 50090, Estonia \\ E-mail: liina.lindstrom@ut.ee
}




\begin{abstract}
Abbreviations
3 - third person, ADE - adessive, ALL - allative, CLI - clitic, CONNEG connegative, ELA - elative, GEN - genitive, INE - inessive, NEG - negative, NOM - nominative, PART - particle, PL - plural, PRT - partitive, PST - past, PTCL - participle, SG - singular, SUP - supine (2nd infinitive)
\end{abstract}

\title{
References
}

Alvre, Paul (2000) “Kirderannikumurde ja vadja keele ühisjooni”. In Jüri Viikberg, ed. Inter dialectos nominaque. Pühendusteos Mari Mustale 11. novembril 2000, 1-13. (Eesti Keele Instituudi toimetised, 7). Tallinn: Eesti Keele Sihtasutus.

Bickel, Balthasar (2010) “Grammatical relations typology”. In J.J. Song, ed. The Oxford handbook of language typology, 399-444. Oxford: Oxford University Press.

Bjarnadóttir, Valgerður and Merlijn De Smit (2013) "Primary argument case-marking in Baltic and Finnic". Baltu filologija 22, 1, 31-65.

Blokland, Rogier (2009) The Russian loanwords in literary Estonian. (Veröffentlichungen Der Societas Uralo-Altaica, 78). Wiesbaden: Harrassowitz Verlag.

Čekmonas, Valeriy (2001) "Russian varieties in the southeastern Baltic area. Rural dialects”. In Östen Dahl and Maria Koptjevskaja-Tamm, eds. Circum-Baltic languages 1: Past and present, 101-136. Amsterdam and Philadelphia: John Benjamins.

Dowty, David (1991) "Thematic proto-roles and argument selection". Language 67, 3, $547-619$.

Erelt, Mati (2005) "Source-marking resultatives in Estonian". Linguistica Uralica 41, $1,20-29$.

Erelt, Mati, Reet Kasik, Helle Metslang, Henno Rajandi, Kristiina Ross, Henn Saari, Kaja Tael, and Silvi Vare (1993) Eesti keele grammatika II. Süntaks. Lisa: Kiri. Tallinn: Eesti Teaduste Akadeemia Keele ja Kirjanduse Instituut.

Erelt, Mati and Helle Metslang (2006) "Estonian clause patterns - from Finno-Ugric to Standard Average European”. Linguistica Uralica 42, 4, 254-266.

Eriksen, Pål K., Seppo Kittilä, and Leena Kolehmainen (2015) "The world is raining. Meteorological predicates and their subjects in a typological perspective”. In MarjaLiisa Helasvuo and Tuomas Huumo, eds. Subjects in constructions - canonical and non-canonical, 205-228. (Constructional Approaches to Language, 16.) Amsterdam and Philadelphia: John Benjamins.

Hakanen, Aimo (2001) "Meteorologisten ilmausten syntaksia ja semantiikkaa". Keele kannul. Pühendusteos Mati Erelti 60. sünnipäevaks 12. märtsil 2001, 62-78. (Tartu Ülikooli eesti keele õppetooli toimetised, 17.) Tartu: Tartu Ülikool.

Hakulinen, Auli and Fred Karlsson (1979). Nykysuomen lauseoppia. Helsinki: Suomalaisen Kirjallisuuden Seura.

Hakulinen, Auli, Maria Vilkuna, Riitta Korhonen, Vesa Koivisto, Tarja Riitta Heinonen, and Irja Alho (2004). Iso suomen kielioppi. Helsinki: Suomalaisen Kirjallisuuden Seura. Available online at $<\mathrm{http} / / /$ scripta.kotus.fi/visk $>$. Accessed on 02.06.2017. 
Helasvuo, Marja-Liisa and Tuomas Huumo (2010) “Mikä subjekti on?”. Virittäjä, 2, 165-195.

Hoop, Helen de and Peter de Swart, eds. (2008) Differential subject marking. (Studies in Natural Language and Linguistic Theory, 72). Dordrecht: Springer.

Huumo, Tuomas (2001) "Subjektin kvantiteetti ja verbin aspektitulkinta paljaan partitiivisubjektin konstruktiossa”. Keele kannul. Pühendusteos Mati Erelti 60. sünnipäevaks 12. märtsil 2001, 113-131. (Tartu Ülikooli eesti keele õppetooli toimetised, 17.) Tartu: Tartu Ülikool.

Huumo, Tuomas (2003) "Incremental existence: the world according to the Finnish existential sentence". Linguistics 41, 3, 461-493.

Huumo, Tuomas and Marja-Liisa Helasvuo (2015) "On the subject of subject in Finnish”. In Marja-Liisa Helasvuo and Tuomas Huumo, eds. Subjects in constructions - canonical and non-canonical, 13-41. (Constructional Approaches to Language, 16). Amsterdam/Philadelphia: John Benjamins.

Huumo, Tuomas and Liina Lindström (2014) "Partitives across constructions: on the range of uses of the Finnish and Estonian 'partitive subjects'." In Silvia Luraghi and Tuomas Huumo, eds. Partitive cases and related categories, 153-176. (Emprical Approaches to Language Typology, 54.) Berlin and Boston: de Gruyter Mouton.

Juhkam, Evi (1992) “Eestirootslastest”. Keel ja Kirjandus 7, 394-402.

Juhkam, Evi (1998) Eesti-rootsi murdekontaktid. Unpublished MA thesis. Tallinn University, Faculty of Philology.

Juhkam, Evi (2012) Harju-Madise murrak. Tallinn: Eesti Keele Sihtasutus.

Juhkam, Evi and Aldi Sepp (2000) Läänemurde tekstid. Eesti murded VIII. Tallinn: Eesti Keele Instituut.

Koptjevskaja-Tamm, Maria and Bernhard Wälchli (2001) "The Circum-Baltic languages: an areal-typological approach". In Östen Dahl and Maria KoptjevskajaTamm, eds. Circum-Baltic languages. Vol. 2: Grammar and typology, 615-750. (Studies in Language Companion Series, 55.) Amsterdam and Philadelphia: John Benjamins.

Laanest, Arvo (1975) Sissejuhatus läänemeresoome keeltesse. Tallinn: Eesti NSV Teaduste Akadeemia Keele ja Kirjanduse Instituut.

Lambrecht, Knud (1994) Information structure and sentence form: topic, focus, and the mental representations of discourse referents. (Cambridge Studies in Linguistics, 71.) Cambridge: Cambridge University Press.

Larjavaara, Matti (1991) “Aspektuaalisen objektin synty”. Virittäjä 95, 4, 372-408.

Larsson, Lars-Gunnar (2001) "Baltic influence on Finnic languages". In Östen Dahl and Maria Koptjevskaja-Tamm, eds. Circum-Baltic languages. Vol. 1: Past and present, 237-253. Amsterdam and Philadelphia: John Benjamins.

Lees, Aet (2008) "The partitive case in existential and copula clauses in Balto-Finnic". In Timothy Jowan Curnow, ed. Selected papers from the 2007 Conference of the Australian Linguistic Society. Available online at $<\mathrm{http}$ ://www.als.asn.au/proceedings/als2007/lees.pdf $>$. Accessed on 21.04.2017.

Lees, Aet (2015) Case alternations in five Finnic languages: Estonian, Finnish, Karelian, Livonian and Veps. (Brill's Studies in Language, Cognition and Culture, 13.) Leiden and Boston: Brill. 
Leppik, Eduard (1962) “Subjektist karjala keele Valdai murrakus”. Emakeele Seltsi aastaraamat 8, 171-183.

Lindström, Liina (2011) “Existential constructions in spoken Estonian”. Paper presented at the conference Grammar and Context III: New Approaches to the Uralic Languages, 19.-21.4.2011. Budapest.

Lindström, Liina (2013) "Between Finnic and Indo-European: variation and change in the Estonian experiencer-object construction”. In Ilja A. Seržant and Leonid Kulikov, eds. The diachronic typology of non-canonical subjects, 139-162. (Studies in Language Companion Series, 140.) Amsterdam and Philadelphia: John Benjamins.

Lindström, Liina and Kaili Müürisep (2009) "Parsing corpus of Estonian dialects". NEALT Proceedings Series 8, 22-29. Available online at $<\mathrm{http}$ ://dspace.ut.ee/ handle/10062/14288>. Accessed on 21.04.2017.

Lyons, Christopher (1999) Definiteness. Cambridge: Cambridge University Press.

Metslang, Helena (2012) "On the case-marking of existential subjects in Estonian". SKY Journal of Linguistics 25, 151-204.

Metslang, Helena (2014) "Partitive noun phrases in the Estonian core argument system". In Silvia Luraghi and Tuomas Huumo, eds. Partitive cases and related categories, 177-255. (Empirical Approaches to Language Typology, 54.) Berlin and Boston: de Gruyter Mouton.

Metslang, Helle and Mati Erelt (2008) "Kogeja vormistamine eesti keeles: nihkeid SAE perifeerias". Emakeele Seltsi aastaraamat 53, 9-22.

Metsmägi, Iris, Meeli Sedrik, and Sven-Erik Soosaar (2012) Eesti etümoloogiasõnaraamat. Tallinn: Eesti Keele Sihtasutus.

Miestamo, Matti (2014) "Partitives and negation: a cross-linguistic survey". In Silvia Luraghi and Tuomas Huumo, eds. Partitive cases and related categories, 63-86. (Empirical Approaches to Language Typology, 54.) Berlin and Boston: de Gruyter Mouton.

Mihkla, K., L. Rannut, E. Riikoja and A. Admann (1974) Eesti keele lauseõpetuse põhijooned I. Lihtlause. Tallinn: Valgus.

Must, Mari (1965) "Vene-eesti kakskeelsus Kirde-Eestis". In H. Moora and L. Jaanits, eds. Slaavi-läänemeresoome suhete ajaloost, 107-131. Tallinn: Eesti Raamat.

Must, Mari (1987) Kirderannikumurre. Tallinn: Valgus.

Must, Mari (2000) Vene laensõnad eesti murretes. Tallinn: Eesti Keele Sihtasutus.

Nemvalts, Peep (2000) Aluse sisu ja vorm. Alusfraasi käändevaheldus tänapäeva eesti kirjakeeles. Tallinn: Eesti Keele Sihtasutus.

Pajusalu, Karl (1996) Multiple linguistic contacts in South Estonian: variation of verb inflection in Karksi. (Publications of the Department of Finnish and General Linguistics of the University of Turku, 54.) Turku.

Pajusalu, Karl and Arvo Krikmann (2000) "Kus on keskmurde keskpunkt?” In Jüri Viikberg, ed. Inter dialectos nominaque. Pühendusteos Mari Mustale 11. novembril 2000, 131-172. Tallinn: Eesti Keele Sihtasutus.

Pall, Valdek (1982) "Idamurde vahekorrast naabermurretega ja vadja keelega". Keel ja Kirjandus 25, 5, 246-251. 
Partee, Barbara H., Vladimir Borschev, Elena V. Paducheva, Yakov Testelets, and Igor Yanovich (2011) "Russian genitive of negation alternations: the role of verb semantics”. Scando-Slavica 57, 2, 135-159.

Prince, Ellen F. (1981) “Toward a taxonomy of given-new information”. In P. Cole, ed. Radical pragmatics, 223-255. New York: Academic Press.

Rannut, Lehte (1964) “Täis- ja osaalus tänapäeva eesti kirjakeeles”. Keel ja Kirjandus 7, 1, 32-39.

Sedrik, Meeli (1999) "Hiiu murraku kontaktidest eestirootsi murretega. Taustast". In Karl Pajusalu and Tõnu Tender, eds. Õdagumeresoomõ veeremaaq. Läänemeresoome perifeeriad, 140-151. (Publications of Võru Institute, 6.) Võro.

Seržant, Ilja A. (2014) "The independent partitive genitive in North Russian”. In Ilja A. Seržant and Björn Wiemer, eds. Contemporary approaches to dialectology: the area of North, Northwest Russian and Belarusian vernaculars, 270-329. (Slavica Bergensia, 13.) Bergen: John Grieg AS.

Seržant, Ilja A. (2015) "The independent partitive as an Eastern Circum-Baltic isogloss". Journal of Language Contact 8, 341-418.

Timberlake, Alan (2004) A reference grammar of Russian. Cambridge: Cambridge University Press.

Vaba, Lembit (2011) "Kuidas läti-eesti keelekontakt on mõjutanud eesti murdekeele grammatikat ja sõnamoodustust”. Emakeele Seltsi aastaraamat 56, 204-246.

Viberg, Åke (2010) "Swedish impersonal constructions from a crosslinguistic perspective: an explanatory corpus-based study". Orientalia Suecana 59, 122-158.

Kokkuvõte. Liina Lindström: Partitiivsubjekt eesti murretes. Nominatiivipartitiivi vaheldumine subjekti markeerimisel toimub eesti keeles peamiselt eksitentsiaallausetes ja sellega sarnastes konstruktsioonides. Artiklis mõõdetakse partitiivsubjekti esinemissagedust eesti murretes, et leida, kas murrete vahel on olulisi erinevusi partiivsubjekti kasutamisel, ja kas neid erinevusi saab selgitada keelekontaktide mõjuga. Lisaks vaadeldakse konstruktsioone, kus partitiivsubjekt üldse võib esineda. Andmed on pärit eesti murrete korpusest (12 eri murrakut, kokku 1517 partitiivsubjekti kasutusjuhtu). Artiklist selgub, et partitiivsubjekti kasutuse põhjal on eesti murded küllalt sarnased. Pisut vähem kasutati partitiivsubjekti Põhja-Seto tekstides, kus see oli tugevamalt seotud eitusega kui mujal. Eitus oli ka üldiselt kõige olulisem partitiivsubjekti kasutamist mõjutav tegur (52\% partitiivsubjektiga lausetest olid eitavad).

Võtmesõnad: murdesüntaks, partitiivsubjekt, eristav subjekti markeerimine, eesti murded 